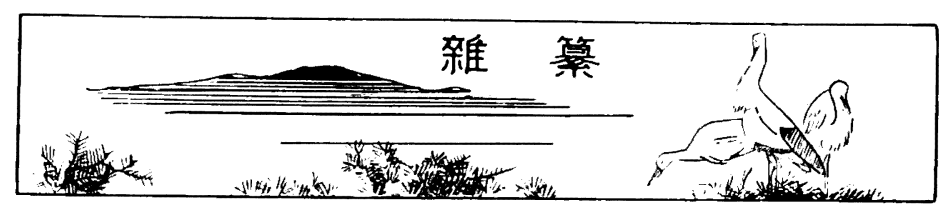

\title{
A Fourth lot of Bird-skins from Manchuria
}

\author{
By
}

Nagamichi Kuroda, D. Sc.

Mr. K. Mizuno has collected the following skins in Manchuria and sent me for identification. Among this collection, Siphia mugimaki, Hemiguristic enlophotes and Porzana fusca erythrothorex seen to be new to the avifauna of Manchuria.

\section{Family LANIIDE.}

1. Lanius sphenocercus sphenocercus Cabanis.

q ad.. Godôkô, 8. x. 1931 (no. 16). Wing 12:; tail 142.5; tarsus 32.5 ; exposed culmen 17 ; entire culmen $29 \mathrm{~mm}$.

This fine skin of the autumn plumage has its sides of body washed with pale greyish rosy.

\section{Family MUSCICAPID.E.}

2. Siphia mugimaki (Temminck).

đै ad., Chinkō-zan, 13. v. 1930 (no. 17). Wing $7.5 \mathrm{~mm}$.

\&, Godôkô, 19. v. 1931 (without number). Wing $65.5 \mathrm{~mm}$.

This $\delta$ skin has its plumage very fine while the $q$ is duller and somewhat faded.

Family TURDIDR.

3. Saxicola torquata stejnegeri (Parrot).

ㅇ ad., Godôkô, 15. x. 1931 (no. 18). Wing 66.5 mm.

Family CUCULIDA.

4. Hicrococcyx fugax hyperythrus (Gould). ${ }^{2}$

q juv., Godôkô, 27. v. 1931 (no. 15). Wing $193 \mathrm{~mm}$.

1) Cf. "Tori," Vol. vii, no. 32, pp. 184-18i (Dec, 1931 ).

2) $C f$. Stresemann, J. f. O., 1930, p. 306. 
Family STRIGIDA.

5. Strix uralensis [? japonica or ? nikolskii].

\& juv., Ichimenha (一面坡), x. Manchuria, 14. vii. 1931 (no. 20). Wing $29 s$, tail $195 \mathrm{~mm}$.

This young specimen has much greyer quills and rectrices than in japonica from Hokkaido, Korea and Chôshun in S. Manchuria, but other parts of body still with juvenile downy feathers, so that I cannot determine the subspecitic name.

\section{Family FALCONIDA.}

(i. Accipiter nisus nisosimilis (Tickell).

¿ jur.. Godôkô, s. x. 1931 (no. 14). Wing $205 \mathrm{~mm}$.

This youn: 2 of the form has very distinct rufous margins to the feathers on head, upper mantle, rump, upper tail-coverts and wingcoverts: the underjarts, except chin and throat, are also strongly barred or mottled with rufous and dark brown; tail-feathers margined with cinnamon-rufru:

\section{Family ARDEIDA.}

7. Hemigarzetta eulophotes (Swinhoc).

: (juv.?). Nanshi (南市), 11. x. 1931 (no. 21). Wing 248; tarsus :1; expu-ed culmen 76.5 ; tail $\$ 4 \mathrm{~mm}$.

Cpper mandille and tip (29 mm.) of lower mandible black (with extreme tip horny); basal half of sides of upper mandible and hasal twothirds of lower mandible yellow (from a month older skin).

The nuchal erest of this specimen is very short, only $39 \mathrm{~mm}$. in length.

This is probally the first time that the egret is recorded from Manchuria. though it is known from tossuri in summer.

Family ANATIDA.

s. Querquedula querquedula (Linnæus).

z ad. (breeding phunage), Ryôga, 3. iv. 1931 (no. 7). Wing 185 mm.

Inderparts especially the chest is very strongly stained with rusty.

9. Nyroca rufa baeri (Radde).

† ad., Eikô, 24. iii. 1928 (no. 3). Wing $198 \mathrm{~mm}$. 
\& al., Ryôga, 3. iv. 1931 (no. 1). Wing $207 \mathrm{~mm}$.

This pochard is one of the rarest diving ducks in Japan, but it seems to be not very rare in $\mathrm{S}$. Manchuria.

10. Nyrocia fuligula (Linnæus).

$\$$ ad., no loc. and no date (no. i) . Wing $190 \mathrm{~mm}$.

juv., Eikô, ¿2s. iii. 1927 (no. 5). Wing $190 \mathrm{~mm}$.

11. Nyroca marila mariloides (Vigors).

\& ad., Yalu River, 1. iv. 1931 (no. 4). Wing $00.5 \mathrm{~mm}$. With of white patch near base of bill $14 \mathrm{~mm}$. Back with rather distinct vermiculations.

12. Bucephala clangula clangula (Linnæus).

우 juv., Ryôga, 24. iii. 1928 (no. 2). Wing $202 \mathrm{~mm}$.

Lnderparts is very distinctly stained with rusty, epecially so on the chest.

Family SCOLOPACIDA.

13. Erolia alpina sakhalina (Vieillot).

of ad. hiem., Nanshi, 11. x. 1931 (no. 9). Wing 115. "xpused culmen $36 \mathrm{~mm}$.

Family CHARADRIIDE.

14. Pluvialis apricarius fulvus (Gmelin).

ơ juv., Santô Rôtô (三頭派頭), 15. ix. 1931 (no. 13). Wing 167.5 $\mathrm{mm}$.

Family LARIDA.

15. Chlidonias leucoptera (Temminck).

$q$ juv. in 1st plumage. Yalu River, 14. ix. 1931 (n॰. ५). Wing 194, tail 71.5; tarsus 18; exposed culmen $23 \mathrm{~mm}$.

Familly RALLID $A$.

16. Rallus aquaticus indicus Blyth.

q ad., Yûgakujô, vi. 1927 (no. 10). Wing $139 \mathrm{~mm}$.

17. Porzana fusca erythrothorax (Temm. \& Schl.).

† ad., Yûgakujô, 10. vii. 1927 (no. 12). Wing $107 \mathrm{~mm}$.

This specimen has a very pale vinous-red chest. It seems to be faded in this season (July). 
18. Porzana paykullii (Liungh).

đo ad., Shichidôkô (安東七道满), 6. vi. 1929 (no. 11). Wing 129.5 $\mathrm{mm}$.

Chest very deep cinnamon rufous and sides of chest deep reddish chestnut.

19. Gallicrex cinerea (Gmelin).

$\delta$ ad., Suigenchi at Antô, 3. vi. 1928 (no. 21). Wing 207 ; culmen including shield $63 \mathrm{~mm}$.

q juv., Rokudôkô, 4. viii. 1931 (no. 22). Wing 161; culmen including shield $41 \mathrm{~mm}$.

\section{房 總 の 烏 界 (四)$$
\text { 第 藤 源 三 郎 }
$$ \\ 47. マ ヒ}

渡り鳥にして年に依りて、多數渡來するとさと、板少数の渡來するて とつあり。

大正 13 年、多数渡來す。昭和 3 年、少数渡來す。

同 14 年、少數渡來す。同 4 年、同。

同 15 年、同。间5年、同。

昭和 2 年、多數渡來す。

\section{8. カハラヒワ}

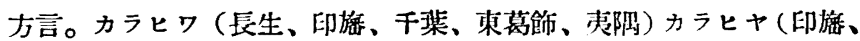
千葉) カラヒバ(長生、安房) コロヒワ（市原）キョロヒ八（市原）以上 は何れも誂れるもの。ヒワ(山武) 略せるもの。カハラヒバリ（君津）河 原に捿さために。

鳴聲。ジェンー、ジェンー（辰生）チイ、チイ(安房)。

棲息多し、千柋市の如を人家桐密なる所几てる庭園に來りて管巢する。 昭和二年千葉市七二六木村遖樹氏の庭の梅樹几營巢して、三㹯隹立す。 昭和四年葉日千葉市七二.六中村氏のア 